\title{
STOCK EXCHANGE IISTING AGREEMENTS AS A VEHICLE FOR CORPORATE GOVERNANCE
}

\section{INTRODUCTION}

After nearly two hundred years of operation, stock exchanges remain largely unexplored as vehicles for regulating the internal affairs of corporations whose stocks they list for trading. Such regulation would seek to establish uniform, easily comprehensible standards of corporate conduct and to communicate them to every investor. The standards would be implemented by requiring that corporations conform to them as a prerequisite to having their securities traded on an exchange. As a result, investors could more accurately assess the value of corporate equity securities than they can today, and would be less likely to base an investment decision on a misunderstanding of their potential rights as shareholders. ${ }^{1}$

In evaluating the price of an equity security today, investors face fifty state corporation laws and as many state judicial systems, which together determine the bundle of rights the investor purchases. This problem stems from the principle that state law defines the rights and obligations a corporation owes to its shareholders. ${ }^{2}$ Investors who have neither the expertise to school themselves in the nuances of state corporation law nor the resources to hire an attorney for that purpose ${ }^{3}$ may choose "safer" investments, ${ }^{4}$ or equally risky but more understandable investments, ${ }^{5}$ or

I Stock exchanges currently regulate some aspects of internal corporate affairs, see, e.g., note 40 infra, but this Comment advocates greater supervisory powers. Furthermore, because of the relative obscurity of listing agreement provisions, investors do not generally appreciate the specifics of current exchange regulations.

2 " 'Corporations are creatures of state law' and it is state law which is the font of corporate directors' powers." Burks v. Lasker, 441 U.S. 471,478 (1979) (quoting Cort v. Ash, 422 U.S. 66, 84 (1975)). See also Restatenent (SECOND) OF CONFLICT OF LAwS \$\$301-13 (1971) (distinguishing laws applicable to internal corporate affairs from those applicable to external affairs).

3 For example, the NYSE reported that over $80 \%$ of stock sales in 1979 were in blocks of less than 900 shares, and that $31.6 \%$ involved less than 100 shares. The comparable figures for 1978 were 83\% and 32.9\%. UNITEd States Dep'T of ComMERCE, 1980 Statistical Abstract of tee United States 545. In 1975, 17 million Americans with incomes of $\$ 25,000$ or less owned stock, as opposed to 7 million with incomes over $\$ 25,000$. Id. 547 .

4 Domestic commercial banks held 666.6 billion dollars in time deposits in April 1980 , id. 534, and savings and loan associations held 470.2 billion dollars in savings in $1979, i d .536$. These investments yield a relatively low rate of return, and some substantially punish investors who reclaim their deposits before maturity.

5 For example, uninsured morrey markets have experienced astonishing growth during recent years. See, e.g., Delaware Cash Reserve Quarterly Report I (June 
may select corporate securities in some uninformed way. 6 The first two choices divert money from industry and capital formation, and the third means that investors do not adequately understand the various economic and legal rights they receive by investing in the corporation. $^{7}$ If investors then suffer losses because they inadequately appraised their rights, they must rely for redress on ad hoc rules, such as the directors' fiduciary obligation to the corporation, promulgated by the judiciary. Investors cannot currently rely on "the market," in this case the exchange, to protect them by setting standards of corporate behavior and disciplining wrongdoers.

An efficient market-based system of determining, and then protecting, shareholder rights depends on participants in the marketplace forming an accurate set of expectations. The accuracy of these expectations, and the degree to which investors can prudently rely on them, depends in part on the amount of information available. ${ }^{8}$ Encouraging investors to seek additional information by making it more readily and cheaply available increases the likelihood of sound investment decisions. This, in turn, increases the probability that investors will return for "another try" at the market. Thus, corporate growth, capital formation, and industrial expansion would be likely to result from replacing investors' present after-the-fact legal protection with before-the-fact market protection.

Stock exchanges can provide the information to make investment decisionmaking more informed. But exchanges are not limited to spreading information. They can also substantially decrease the amount or variety of information necessary for investment decisions by standardizing the legal rules governing investment contracts. $^{9}$ Due to their expansive grant of authority, exchanges ${ }^{10}$

25,1981 ) (" $[A]$ ssets . . . today exceed $\$ 1.4$ billion . . . . [T]his figure is almost three times larger than just one year ago when our assets stood at only $\$ 539$. million").

${ }^{6}$ See, e.g., B. Maxkiex, A Random Wark Down Wall Strket (college rev. ed. 1975).

7 See, e.g., id.

8 The accuracy of information available also depends upon the costs of supervising the marketplace.

9 Recently, large brokerage houses began using legal analysts to calculate the likely success or failure of suits against corporations. These economies of scale are, obviously, not available to the average investor. See note 3 supra. Standardizing. legal rules applicable to corporations would make the outcome of an average investor's suit more predictable and would simultaneously reduce the need for brokers"
"legal work."

10 The Securities Exchange Act of 1934, $\$ 6(\mathrm{~b})$, I5 U.S.C. $\$ 78 f(b)$ (1976), provides that "[a]n exchange shall not be registered as a national securities exchange 
could approach "corporate governance" issues quite flexibly. By developing, interpreting, and applying new rules, exchanges would contribute significantly to the predictability of corporation law by ending the investors' nightmare of fifty separate legal systems. ${ }^{11}$

The stock exchanges' major vehicle for regulating corporate conduct is its listing agreement with the corporation.12 By requiring the listed corporation to follow various provisions and reservations in the agreement, stock exchanges can effectively govern aspects of the corporation's internal affairs. Corporate governance by listing agreement is not a novel idea and, to a limited extent, has been in effect for nearly a century. ${ }^{13}$ But the full extent to which these agreements can be used to protect investors has yet to be realized.

Past underutilization of the exchanges' listing agreement powers may stem in part from the legal uncertainties surrounding a fullscale movement into corporate governance. Even present listing

unless the Commission determines that - ... [its] rules . . . are designed to prevent fraudulent and manipulative acts and practices, to promote just and equitable principles of trade ... and, in general, to protect investors and the public interest."

11 Stock exchanges should be less reluctant than states to stiffen corporate regulations. For states must always contend with the possibility that too much regulation will lead the corporation to move its headquarters, harming that state's tax base and employment prospects. Furthermore, states are generally jealous of their right to make their laws independently.

Furthermore, even if the market-based regulatory system failed, requiring an investor to consider seeking judicial intervention, the increased certainty of corporate law that would result from "listing agreement regulation" would assist the investor in making a correct decision whether to sue. Vexatious suits would not be avoided, but those based upon misunderstandings of, or uncertainties about, the law likely would be.

12 Listing agreements are simply a number of requirements, in the nature of restrictive covenants, that a corporation must agree to if it wishes its shares to be publicly traded on a national securities exchange. For example, the New York Stock Exchange (NYSE) requires that listed corporations have at least 2000 shareholders holding 100 or more shares. 2 NYSE GumE (CCH) I 2495B (1976).

13 See R. Sobet, The Big BoArd 114 (1965). The most recent use of listing agreements to effect corporate regulation occurred in 1977, when the NYSE adopted a requirement that all listed corporations establish an "audit committee" of independent outside directors. Sec. Act Rel. No. 34-13245 (Feb. 4, 1977), reprinted in 2 NYSE GumE (CCH) [ 2495H (1980).

Audit committees examine financial statements produced by the corporation's outside auditors to insure that they accurately reflect the corporation's activities. For a description of the work of such committees, see ABA Committee on Corporate Laws, The Overview Committees of the Board of Directors, 35 Bus. LAw. 1335 (1980). There is a growing consensus that audit committees can be a significant addition to the functions of the board of directors. See Statement of the Business Roundtable, The Role and Composition of the Board of Directors of the Large Publicly Owned Corporation, 33 Bus. LAw. 2083, 2108 (1978). See also SEC v. Killearn Properties, Inc., [1977-78 Transfer Binder] FED. SEC. L. REP. (CCH) If 96,256 (N.D. Fla. 1977) (consent decree requiring establishment of an audit committee); 533 SEC. REG. \& L. ReP. (BNA) A-10 (Dec. 19, 1979) (AMEX Board of Governors recommends audit committees for listed firms). 
agreements, with their limited intrusions into corporate boardrooms, are subject to potential legal attack. More stringent listing requirements, by more frequently "coercing" corporate activities, will further emphasize that these regulations emanate from private bodies rather than from traditional, governmental sources. ${ }^{14}$ Three arguments would likely be raised against governance of corporate conduct by court enforcement of listing agreements. ${ }^{15}$

First, it might be argued that enforcement of certain listing agreement provisions would constrain the internal operations of listed corporations, thereby exceeding the authority delegated to the exchanges by the federal securities laws. Second, it could be contended that enforcement of listing agreement provisions intrudes on a substantive area of law reserved to the states, therefore violating principles of federalism. Third, it may be suggested that certain listing agreement provisions violate the antitrust laws by restraining trade.

This Comment concludes that only the first of these legal problems poses a serious threat to listing agreement enforcement. Part I discusses necessary background information, tracing the history of listing agreements. Part II discusses the framework within which a challenge to listing agreements' legality is likely to occur, resolving difficult questions about who will be able to enforce listing agreements and who may challenge an exchange's failure to do so. Part III addresses the merits of the legal arguments against listing agreements' validity. Finally, part IV presents a proposal that avoids the potential difficulty posed by the argument that enforcing listing agreements exceeds stock exchanges' legal authority.

\section{BACKGROUND}

\section{A. The Rise of Listing Requirements}

The origins of listing agreements lie in the growth of national stock exchanges and, in particular, the New York Stock Exchange

14 This problem of private versus governmental regulation is the critical policy issue presented by the suggestion that listing agreements be used to effect corporate governance. The private, market-based approach advocated by this Comment makes governance largely a matter of quasi-contractual agreement. But it removes control over a large number of investors' financial resources from the political process, and makes it less likely that those investors can affect the rules that govern the companies they invest in.

15 Delisting, which removes the violator's securities from the exchange and prevents exchange members from trading the violator's stock, is the most severe sanction available to exchanges in enforcing the listing agreements. See generally 2 NYSE Gume (CCH) $\{2499$ (1978). 
(NYSE). ${ }^{16}$ From the earliest development of exchanges, the NYSE was dominant, its members trading the highly desirable securities issued by the soundest companies. ${ }^{17}$ In the 19th century, the NYSE consolidated its virtual monopoly, placing restrictions on the securities it permitted its members to trade. ${ }^{18}$ These restrictions included provisions about the acceptable size and profitability of companies whose securities could be traded; minimum shareholder requirements to insure broad ownership, and rudimentary disclosure of the companies' financial position. ${ }^{19}$ Thus, from earliest times, stock exchanges have determined certain aspects of corporate conduct. $^{20}$

With the enactment of the securities laws of $1933^{21}$ and $1934,{ }^{22}$ federal law took on part of the burden of regulating corporate conduct. These laws required ${ }^{23}$ exchanges to promulgate and enforce $^{24}$ various restrictions on their members, 25 on listed cor-

16 See generally R. SobEL, THE BIG BOARD 81-144 (1965). Other exchanges originated with the NYSE, such as the Curb Exchange, a smaller competitor in New York which eventually became the American Stock Exchange. Regional exchanges also grew up, achieving varying degrees of success. See generally J. Walter, The Role of Regronal Securtty Exchanges (1957).

17 See R. SobEx, supra note 16 , at 83-87.

18 See id. 85. (1980).

19 NYSE Company Manual A-32. See 2 NYSE Gume (CCH) đT 2495B-95C

20 For a useful history of early stock exchange disclosure requirements, see Benston, Required Disclosure and the Stock Exchange Market: An Evaluation of the Securities Exchange Act of 1934, 63 AM. Econ. REv. 132 (1973).

21 Securities Act of 1933, ch. 38, $\$ \S 1-328,48$ Stat. 74 (1933) (codified at 15 U.S.C. $\$ \$ 77 a-77 a a(1976$ \& Supp. III 1979)).

22 Securities Exchange Act of 1934, ch. 404, $\$ 1-211,48$ Stat. 881 (1934) (codified at 15 U.S.C. $\$ \$ 78 \mathrm{a}-78 \mathrm{kk}$ (1976 \& Supp. III 1979)).

23 Section 5 of the 1934 Act demonstrates that exchanges must comply with its provisions by rendering transactions in securities on an exchange unlawful unless that exchange is registered or has been explicitly exempted from registration. 15 U.S.C. $\$ 78 \mathrm{e}(1976)$.

24 See, e.g., 2 NYSE Gume (CCH) $\llbracket 1653$ (1978) (expulsion and suspension from membership-disciplinary proceedings); 2 AM. STock Ex. Gume (CCH) I 9040 (1978) (discipline of members-procedure); id. I 9042 (1980) (suspension in view of financial or operating conditions); $i d$. $\llbracket 9043$ (1980) (suspension or expulsion); NASD Gume (CCH) I2205 (1975) (suspension for failure to furnish information). See also 1934 Act, $\$ 6(\mathrm{~b}) 1,6,15$ U.S.C. $\$ 78 f(b)(1),(6)$ (1976) (specifying that the SEC shall not register an exchange unless the exchange demonstrates the ability to enforce its rules). For a critique of the insufficiency of restraints currently placed on such powers to discipline exchange members, see Lowenfels, The Lack of Fair Procedures in the Administrative Process: Disciplinary Proceedings at the Stock Exchanges and the NASD, 64 ConNeLI L. Rev. 375 (1979).

25 For example, NYSE Rule 390 generally forbids stock exchange members and their agents from trading listed securities in over-the-counter markets. 2 NYSE Gome (CCH) I2390 (1978). Yet nothing in sections 5 or 6 of the 1934 Act requires this prohibition. 
porations, ${ }^{26}$ and on themselves. ${ }^{27}$ Moreover, these Acts established the principle of self-regulation in the securities industry, making stock exchanges and similar organizations responsible for surveillance over the transactions taking place in their facilities. ${ }^{28}$

By 1975,29 Congress was apparently persuaded that this selfregulatory system needed an overhaul. ${ }^{30}$ By passing the Securities Acts Amendments of $1975,{ }^{31}$ Congress reallocated regulatory responsibilities among the stock exchanges and the Securities and Exchange Commission (SEC or Commission), greatly enhancing the Commission's power. ${ }^{32}$ Even so, the exchanges retain significant ability to control corporate conduct through listing agreements.

28 For instance, section 13 (a) of the 1934 Act requires those companies whose securities are traded on the exchange to publish periodic disclosures of operations. 15 U.S.C. $\$ 78 \mathrm{~m}(\mathrm{a})$ (1976). Form $10 \mathrm{~K}$ specifies the required information, 17 C.F.R. $\$ 249.310$ (1980), and the SEC recently took steps to consolidate reporting requirements so that form $10 \mathrm{~K}$ filings do not duplicate annual reports to shareholders and new issue registration.

Corporations must also meet a number of technical prerequisites to listing. See, e.g., 2 NYSE GumE (CCH) I 2495B (1980) (minimum size, profitability, and shareholder distribution requirements).

27 Section 17 of the 1934 Act established an elaborate record-keeping machinery for the operation of the exchanges and their members. 15 U.S.C. $78 q$ (1976). See 17 C.F.R. \$240.17a-1 (1980) (exchange recordkeeping rule).

28 Stock exchanges are the most familiar self-regulating organizations. Others include the National Association of Securities Dealers (NASD), the Municipal Securities Rulemaking Board, and the various industry groups overseeing operation of the security markets.

Self-regulation is generally justified by the complexity of the transactions involved and the need for regulators to be intimately familiar with the regulated markets. See S. Rep. No. 75, 94th Cong., 1st Sess. 46 (1975) reprinted in [1975] U.S. Code Cong. \& AD. NEws 175, 223-24. For an excellent description of the role of self-regulation in the scheme of securities law, see Address by M. Cohen, Competition, Regulation and Self-Regulation in the Securities Industry (U. Pa. Center for the Study of Financial Institutions, Nov. 18, 1974).

29 The most important pre-1975 amendments were in 1938 and 1964 . The 1938 legislation added section 15A, prescribing rules for registration of national securities dealers' associations. Act of June 25, 1938, ch. 677, $\$ 1,52$ Stat. 1070 (codified at 15 U.S.C. $\$ 780-3$ (1976)). The 1964 change standardized disclosure requirements in over-the-counter and exchange markets. Securities Acts Amendments of 1964, Pub. L. No. $88-467, \$ 7,78$ Stat. 574 (codified at 15 U.S.C. $\$ 780-3$ (1976)).

30 Subcomm. on Securties of the Senate Comm. on Bankong, Housing, and Urban Affatrs, Securites Industry Study, S. Doc. No. 13, 93d Cong., 1st Sess. (1973) [hereinafter cited as INDUSTRY STUDY]; SEcunrtIes ACrs AMENDMENTS of 1975, Senate Comm. on BankTng, Housing and Urban Afrairs, S. Rep. No. 75, 94th Cong., Ist Sess. I (1975), reprinted in [1975] U.S. CODE Cong. \& AD. News 179 [hereinafter cited as SENATE REPORT].

31 Securities Act Amendments of 1975, Pub. L. No. 94-29, §2, 89 Stat. 97 (codified at 15 U.S.C. $\$ 78 b(1976)$ ).

32 Senate Report, supta note 30, at 28-31, reprinted in [1975] U.S. Code Cong. \& AD. News at 207-09. 
To be listed on the stock exchange, ${ }^{33}$ a corporation must effectively comply with two sets of federal securities regulations. ${ }^{34}$ First, the corporation must be registered under section 12(b) of the 1934 Act. ${ }^{35}$ Second, the corporate issuer must respond to the exchanges' listing application..$^{30}$ Because section 12 does not mention registration with the stock exchange, or any other provision of the exchange listing agreements, there is no legal requirement that an exchange maintain a different listing procedure from that required by section 12. In practice, however, some aspects of listing agreements generally go beyond section 12 requirements. ${ }^{37}$

Two types of listing agreement provisions are apparent. ${ }^{38}$ First, there are provisions governing size, profitability, and shareholder distribution. ${ }^{39}$ These provisions differ little from section 12

33 Congress also demonstrated particular concern over anticompetitive actions by self-regulatory organizations. See INDUSTRY STuDY, supra note 30 , at 77-79. Thus, it moved strongly to increase competition. See I5. U.S.C. $\$ 78 f(b)(8)$ (1976). See notes 138-66 infra \& accompanying text.

34 Throughout this Comment's analysis, it is important to understand the distinction between exchange rules regarding members and their access to the exchange, and exchange listing agreements with corporate issuers. Members are defined in part as "(i) any natural person permitted to effect transactions on the floor of the exchange without the services of another person acting as broker, . . . [and] to the extent of the rules of the exchange specified by the Commission, any person required by the Commission to comply with such rules." 1934 Act, \& 3, 15 U.S.C. $878 \mathrm{c}(\mathrm{a})(3)(\mathrm{A})(1976)$.

This comment, in using the word "rules," is not referring to the rules that apply to members of the stock exchange as defined above in section $78 \mathrm{c}$ unless explicitly stated. Reference to "rules" will be to those rules applying to corporations listed on a national exchange.

35 The corporation must file an application with both the exchange and the SEC setting forth specified information as required by $\$ 12(\mathrm{~b})(1)$ of the 1934 Act, the regulations thereunder, and SEC Form 10. \$12(b), 15 U.S.C. \$78I (1976); rule $12 b, 17$ C.F.R. $\$ 240.12 b-1$ to $.12 b-36$ (1980).

30 The exchanges' listing application may request different information from that required by section 12. For a side-by-side comparison of the two sets of required disclosures, see 2 FED. SEC. L. REP. (CCH) I 23,095-120 (1981). For an example of the mechanics of the exchange's processing of the application for listing, see NYSE Company Manual B-4 (1978) (preliminary confidential review); 1934 Act, $\$ 12$ (b), 15 U.S.C. $\$ 781$ (d) (1976) (listing effective within thirty days of exchange certification of approval to the SEC).

37 Generally the NYSE has the most restrictive provisions. Furthermore, because most stock trading in regional exchanges is in so-called multiply-listed stocks, the provisions of these exchange listing agreements are not as rigorous. The variation in question, therefore, is largely the increasing stringency from the regional exchanges to the American Stock Exchange (AMEX) to the NYSE.

38 There are, of course, numerous miscellaneous provisions. See, e.g., NYSE Company Manual A-5 (1977) (specifies location and nature of the transfer agent for the securities); $2 d$. A-151 to -164 (specifies the procedure for announcing record dates for voting of shares and receipt of dividends), and other provisions that require procedures for announcing and carrying out stock dividends and splits, rights. offerings and procedures for soliciting proxies.

39 To be listed on the NYSE, the corporation must have at least one million publicly traded shares with a market value of between $\$ 8$ and $\$ 16$ million and at 
requirements. Second, there are provisions that affect corporate conduct in areas such as voting power, matters required to be voted upon by shareholders, classes of directors, and disclosure requirements. ${ }^{40}$ These latter provisions, reaching "corporate governance" issues, raise the major questions of legality.

\section{B. Listing Agreement Enforcement}

The most obvious and commonly employed method of enforcing listing agreements is for the exchange to "delist" violators. The exchange's power to delist comes from its duty, imposed by the securities laws, to enforce its registration requirements. ${ }^{41}$ If, however, an exchange failed to act against an alleged violator, private parties may seek judicial assistance in enforcing the listing agreements. Such a private action might be asserted against the exchange, the listed corporation, or both, and would probably seek damages or an injunction requiring the exchange to delist. Damages could be claimed from either the exchange's failure to delist or the corporation's breach of the listing agreement.

Private suits, unlike exchange delisting powers, are not provided for by securities law. Private parties might seek to maintain an action on the theory that they are third-party beneficiaries of

least 2,000 shareholders holding 100 or more shares. In addition, the corporation must have demonstrated earning power by producing a pre-tax profit of $\$ 2.5$ million in the year prior to listing and at least $\$ 2$ million in each of the two preceding years. This is a bit oversimplified; for a more precise delineation of the numerical requirements, see NYSE Company Manual B-3, -3.1 (1979).

The AMEX and the regional exchanges impose less stringent standards for size and profitability. The AMEX requires a listed corporation to have 800 shareholders of more than 100 shares each and a minimum market value of publicly held shares of $\$ 3$ million. 2 FED. SEC. L. REP. (CCH) $\{23,025.081$ (1980). The Midwest Stock Exchange requires a listed corporation to have 250,000 shares of common stock, with 1,000 holders of at least 100 shares if the value of the stock is less than $\$ 15$ a share, 1,500 holders if the stock value is $\$ 15-50$ a share, 2,500 holders if the stock value is $\$ 50-100$ a share, and 3,000 holders if the value is over \$100 a share. Mmwest Stock Exchange Gume (CCH) I 506 (1967).

The NYSE also maintains a separate and somewhat less stringent set of standards for the maintenance of listed status. NYSE Company Manual B-58 to -78 . The AMEX requires previous year pre-tax income of $\$ 750,000$. 2 FED. SEc. L. REP. (CCH) ף 23,025.081 (1980).

40 NYSE Company Manual A-280 (1977) (non-voting common stock prohibited); id. A-281 (preferred stock with disproportionate voting rights disfavored); id. A-280 (classes of directors limited to three); id. A-283 to -284 (required shareholder vote on option plans for officers and directors; changes in corporate control; significant dealings with insiders, and issuance of securities resulting in a $20 \%$ change in ownership or voting power); id. B-23 (two outside directors on each board suggested); id. A-29 (audit committee of outside directors required); id. A-30 to -3I (defensive "tactics" scrutinized closely); id. A-18, A-22 (time disclosure of material corporate news).

41 See note 24 supra. 
the listing agreement between exchange and corporation. Alternatively, private plaintiffs might argue that their cause of action should be judicially implied. Should both of these approaches prove unavailing, the listing agreement's importance as a vehicle for corporate regulation would be diminished, for actions to enforce its provisions would be initiated only at the exchange's discretion.

The choice between the third-party beneficiary theory and the judicial implication theory of private actions depends upon resolution of the question whether listing agreements are to be treated as private contracts or legal rules. If listing agreements are private contracts between the exchange and the listed corporation, then plaintiffs must establish that they are third party beneficiaries of that agreement. in order to prevail in a lawsuit. If, however, the agreements are legal rules promulgated by the exchange pursuant to delegated regulatory authority, then plaintiffs may be able to prevail by establishing the existence of an implied private right of action under section 6 or section 10 of the Securities Act of 1934 . Because of this distinction's significance for maintaining private actions to enforce listing agreements, this Comment now considers whether the agreements should be treated as private contracts or legal rules.

\section{Contract or Rule?}

The argument that listing agreements are contracts is premised largely upon the parties' voluntary decision to enter into them and accept their terms. Corporations accept listing agreement provisions, as a matter of choice, in order to secure a place on the exchange. But no company is compelled to trade its shares on the exchange, and those deciding to trade only in over-the-counter markets are not obliged to follow listing agreement requirements. In short, listing agreements' contractual nature is arguably evidenced by the lack of compulsion upon the parties and the availability of alternative ways of doing business.

Yet, in a somewhat similar situation involving brokers and dealers, Congress made clear that it did not consider the voluntariness argument sufficient to conclude that members had contracted away their rights to procedural fairness. ${ }^{42}$ Exchanges, even if agreement

42 The Senate Report makes this point as follows:

The Committee is well aware of the historical differences between "membership" in an exchange and in the NASD. The limited number of "seats" on an exchange, as contrasted with the availability of NASD membership to all qualified brokers and dealers, is only the most obvious of these 
provisions are to the contrary, must follow the same sorts of procedures by which nonexclusive organizations are bound. ${ }^{43}$

Congress, then, views broker and dealer agreements with exchanges as rules, at least when due process is concerned. Unfortunately, it has not expressed a view of listing agreements' status. ${ }^{44}$ Nevertheless, in addition to the broker and dealer analogy, the securities statutes and public policy both support treating listing agreements as rules.

Section 19(b) of the 1934 Securities Act requires that modification of listing agreement provisions follow the same notification and approval procedures as rule changes involving broker or dealer members. ${ }^{45}$ By treating modification of listing agreements as changes in broker and dealer agreements, Congress made clear that it considers these two sorts of arrangements procedurally similar. Consequently, Congress's explicit understanding that broker and dealer agreements are rules makes it likely that listing agreements are also rules.

The analogy is reinforced by considering the consequences of each type of agreement. By changing investors' perceptions of the risk involved in selecting a particular corporate security, listing agreements can have as significant an effect on the capital formation process as the broker-dealer trading "rules." 46 Indeed, stock ex-

differences. However, the Committee does not believe that the substantive differences in the two concepts of membership justify any less attention to procedural fairness in the case of the exchanges than in that of the NASD.

SENATE RePoRt, supra note 30 , at 25, reprinted in [1975] U.S. CoDe Cong. \& AD. NEws at 203-04.

43 Id.

44 Case law is also particularly unrevealing. A number of cases seem to assume that listing agreement provisions are rules. See, e.g., Lank v. NYSE, 548 F.2d 61 (2d Cir. 1977); Van Gemert v. Boeing Co., 520 F.2d 1373 (2d Cir.), cert. denied, 423 U.S. 947 (1975). The latter case went so far as to say in dictum that " $[t]$ he listing agreement and Company Manual are 'instruments corresponding' to rules of the Exchange." Id. 1380.

451934 Act, $\$ 19,15$ U.S.C. $\$ 78 \mathrm{~s}(\mathrm{~b})(1)$ (1976) requires exchanges and selfregulatory organizations (SROs) to notify the SEC of proposed rule changes. The Senate Report analogizes rulemaking by SROs to rulemaking by governmental units and sets up procedural analogies to the Administrative Procedure Act. SEnate REPORT, supta note 30 , at 29, reprinted in [1975] U.S. CODE Cong. \& AD. News at 207-08. It is interesting to note that the NYSE listing agreement modification requiring audit committees was approved by the SEC under the 19(b) procedure, adding force to the argument by analogy. See Sec. Ex. Act Rel. No. 34-13245 (Feb. 4, 1977).

46 Senate Report, supta note 30, at 2, reprinted in [1975] U.S. Code Cong. \& AD. NEwS at $180-81$. 
changes, in promulgating regulations through listing agreements, are instructed to remember "at all times that they [are] quasi-public organizations, not private clubs ...." 47

Furthermore, exchanges can impose the severe penalty of delisting on corporations violating the agreements, ${ }^{48}$ thus enforcing standards that differ little from substantive federal rules governing corporate conduct. So it can be argued that delisting, which resembles a punitive measure or civil action, effectively backs listing agreements with the force of law.

Other aspects of listing ageements also support the argument that they are in effect rules of law. Exchanges are partially regulated governmental instrumentalities with a mandate to "protect investors," and the enforcement of listing agreement provisions is not significantly different from an administrative agency enforcing laws or regulations for that purpose. Listing agreements' uniform application to all listed companies, and the potential retroactive application of newly promulgated standards, ${ }^{40}$ also indicate that "rule" is an accurate characterization.

${ }^{47}$ Id. 29, reprinted in [1975] U.S. CODE Conc. \& AD. News at 207.

48 The 1934 Act provides that "[securities] may be withdrawn or stricken from listing and registration in accordance with the rules of the exchange and, upon such terms as the Commission may deem necessary to impose for the protection of investors, upon application by the issuer or the exchange to the Commission." $\$ 12(d)$, I5 U.S.C. $\$ 781$ (d) (1976). SEC regulations give exchanges the power to temporarily suspend trading in a security or to make application to have the security delisted. In instances in which the security has matured, been redeemed, or been replaced, the regulations require that the exchange commence delisting. 17 C.F.R. $\$ 240.12 \mathrm{~d} 2-2(\mathrm{a})$ (1980). In cases where the security has been shifted to trading on another exchange, and an exchange rule exists which requires termination on such an occasion, the regulations give the exchange the power to strike the security from its listing. 17 C.F.R. $\$ 240.12 d 2-2(b)(1980)$. In addition, the regulations empower the exchanges to apply to the SEC for delisting in other cases in accordance with exchange rules. 17 C.F.R. $\$ 240.12$ d2-2(c) (1980). The regulations state that the SEC must approve the request unless it finds that a hearing is necessary to determine whether the application to delist has been made in accordance with the exchange rules and whether specific additional terms are needed for the protection of investors. Id.

Delisting imposes considerable costs on the corporation. In an as yet unpublished and unreleased SEC economic study, Professor Daniel S. Dhaliwal argues that the cost of capital to over-the-counter companies is higher than it is for similar listed companies. See 581 SEc. REg. \& L. REp. (BNA) A-8 (December 3, 1980). Additionally, only designated over-the-counter stocks can be purchased on margin, limiting the market for those other securities. Securities Exchange Act of 1934, $\$ 7,15$ U.S.C. $\$ 78 \mathrm{~g}$ (1976). The over-the-counter market is discussed in S. Robbins, The Securtties Markets (1966).

49 Future changes in the stock exchange listing agreement are not directly retroactive as to previously listed securities; but listing agreements generally require that new securities cannot be listed unless all the securities of the issuer are subject to the current listing agreement strictures. Hence, although not in a strictly literal sense, for many intents and purposes the exchange listing agreements operate retroactively. See, e.g., NYSE Company Manual B-67. 
Enactment of SEC proposed rule $3 \mathrm{~b}-7^{50}$ would clarify listing agreements' legal status. The proposal defines "rules" as "guidelines or standards that a self-regulatory organization employs in a determination to grant or deny access to its facilities." 51 This definition implies that denial of access to self-regulatory organizations is a serious business handicap, so that the power to control access must be subject to strict control. Because listing agreements are used to grant or deny a corporation access to exchange facilities, their provisions are almost certainly within the proposal's definition of rules.

Currently, however, the question is debatable. Because statutory interpretation and public policy favor the construction, this Comment treats listing agreement provisions as legal rules extending federal regulatory power in the securities field..$^{52}$

\section{Private Enforcement of Listing Agreements}

\section{A. Implied Right of Action}

Assuming that listing agreements are construed as legal rules, potential plaintiffs would assert that their right to enforce the provisions should be judicially implied. A private cause of action against the exchange would be based on section 6 of the Securities Act of 1934; suits against the corporate issuer would be based on section 6 or section 10 of the Act.

\section{Private Suits Against the Exchange}

Because no court has recently addressed the question whether a private cause of action against the exchange can be judicially implied, ${ }^{63}$ it is useful to consider judicial treatment of the very similar agreements between exchanges and broker-dealer members. ${ }^{54}$ The most recent case, Rich $v$. NYSE, ${ }^{55}$ held that private causes of

50 Sec. Ex. Act Rel. No. 34-15838 (May 18, 1979), reprinted in [1979] FED. SEC. L. ReP. (CCH) \82,082.

51 Id. $\{82,082$, at 81,808 .

52 See notes 53-87 infra \& accompanying text. Because the rule-contract question is unsettled, this Comment also addresses private actions under the third-party beneficiary theory. See notes 88-95 infra \& accompanying text.

53 Only one case has explicitly addressed the private action question in the context of stock exchange listing agreement violations, and that case was decided prior to the Supreme Court's enunciation of stricter implication standards. Van Gemert v. Boeing Co., 520 F.2d 1373 (2d Cir.), cert. denied, 423 U.S. 947 (1975).

54 See notes 139-66 infra \& accompanying text.

55509 F. Supp. 87 (S.D.N.Y. 1981). See, e.g., Murphy v. McDonnell \& Co., 553 F.2d 292 (2d Cir. 1977); Lank v. NYSE, 548 F.2d 61 (2d Cir. 1977); Hughes v. Dempsey-Tegeler \& Co., 534 F.2d 156 (9th Cir.), cert. denied, 429 U.S. 896 (1976). 
action against brokers and dealers asserted under section 6 had survived the Supreme Court's stiffening of implied right standards. ${ }^{56}$ Because of the similarity between listing and broker-dealer agreements, plaintiffs can argue by analogy with $R i c h$ that a private right should exist in listing agreement cases. ${ }^{67}$

Besides the argument by analogy with broker-dealer agreements, plaintiffs can argue that the lack of other existing remedies supports an implied private enforcement right against the exchange. The Supreme Court, emphasizing that means of enforcing compliance with the statute existed without implication of a private right, appears to have accepted the converse of this argument in Transamerica Mortgage Advisors, Inc. v. Lewis.58 In this case, unlike Transamerica, the statute provides no remedy.

In fact, only two sections of the 1934 Act expressly sanction exchanges for rule violations. Section $19(a)(1)^{59}$ permits outright revocation or suspension of an exchange's registration for up to twelve months. Section $32^{60}$ prescribes a fine for the exchange of not more than $\$ 500,000$. Neither section, however, helps the defrauded investor whom the statute professes to protect, ${ }^{61}$ for "[b]oth [sections] are punitive and remedial measures, rather than compensatory; and while they may be of benefit to future investors, they do nothing for those who have already been the victims . . . " 62

56 The court noted that an implied action under this section had been recognized since the decision in Baird v. Franklin, 14I F.2d 238 (2d Cir.), cert. denied, 323 U.S. 737 (1944). The court concluded that, because Congress had chosen not to omit such an action during the extensive 1975 securities law revisions, see notes 29-32 supra \& accompanying text, it intended that the right continue.

The court also concluded that the asserted action met the four-pronged implied private action test of Cort v. Ash, 422 U.S. 66 (1975), see notes 74-76 infra \& accompanying text, and added further: "[W]here there is a long history of a wellsettled universally accepted implication of an unstated cause of action, I believe ... the Cort test is at least modified, and perhaps overridden, by consideration for those long-standing traditions." 509 F. Supp. at 89.

67 Again, however, it must be emphasized that plaintiffs must show more than that they are simply aggrieved investors. As the Court stated in a similar situation, "the mere fact that the statute was designed to protect [the plaintiff class] does not require the implication of a private cause of action .... The dispositive question remains whether Congress intended to create any such remedy." Transamerica Mortgage Advisors, Inc. v. Lewis, 444 U.S. 11, 24 (1979) (citations omitted).

$58 \mathrm{Id}$. 19 ("[W]here a statute expressly provides a particular remedy or remedies, a court must be chary of reading others into it").

6915 U.S.C. $\$ 78 \mathrm{~s}(\mathrm{~h})(\mathrm{l})(1976)$.

6015 U.S.C. $\$ 78 f$ (1976).

01 Baird v. Franklin, 141 F.2d 238, 245 (2d Cir.), cert. denied, 323 U.S. 737 (1944). Cf. 15 U.S.C. $\$ 78 \mathrm{~s}(\mathrm{~h})$ (I) (1976) (exchange registration may be revoked or suspended "in the public interest, for the protection of investors, or otherwise in furtherance of the purposes of this chapter. ...").

62 Baird, 141 F.2d at 238. 
Given Congress's express intention to protect investors ${ }^{63}$ and its failure to provide a means of doing so, it can be argued that a private cause of action against the exchange must have been intended.

\section{Private Actions Against the Corporation}

The argument for an implied private cause of action against the listed corporation seems somewhat stronger than the case against the exchange. Section 10 of the 1934 Act provides the most persuasive basis for such an argument because an implied cause of action under that section has existed since $1946 .{ }^{\circ 4}$ The plaintiff would contend that listed status on a stock exchange is a representation of trustworthiness, financial capability, and other pertinent corporate characteristics. Thus, violation of the listing agreement would be a misrepresentation to investors within section 10(b)'s proscriptions.

But no court has carefully considered a private right under section 10 in the context of listing agreement violations. The Tenth Circuit, ${ }^{65}$ without thoroughly examining the question, held that a claim of listing agreement violations would not substitute for the requirement of willful or intentional misconduct in a section $10(\mathrm{~b})$ case. $^{66}$ Combined with the Supreme Court's clear intention to curtail any further extension of implied 10 (b) actions, ${ }^{67}$ this holding makes it likely that an effort to extend implied private rights to this area would meet judicial resistance.

Besides section 10, plaintiffs could also assert an implied private right against the corporation under section 6 of the 1934 Act. This action could be based on a number of equitable grounds. For example, in Van Gemert v. Boeing Co., ${ }^{68}$ the Second Circuit suggested that the corporation owed a duty of fairness to its share-

63 E.g., 15 U.S.C. $\$ 78 s(\mathrm{~h})(1)$. See note 61 supra.

64 Kardon v. National Gypsum Co., 69 F. Supp. 512 (E.D. Pa. 1946). The Supreme Court did not face this question until 25 years later when it affirmed the long line of precedent upholding the implied section 10 action. Superintendent of Ins. v. Bankers Life \& Cas. Co., 404 U.S. 6, 13 n.8 (1971).

65 Utah State Univ. v. Bear, Stearns \& Co., 549 F.2d 164 (10th Cir.), cert. denied, 434 U.S. 890 (1977). Accord, State Teachers Retirement Bd. v. Fluor Corp., 500 F. Supp. 278, 294 (S.D.N.Y. 1980).

60 Utah State Univ., 549 F.2d at 169.

o7 E.g., Santa.Fe Indus., Inc. v. Green, 430 U.S. 462 (1977) (section 10(b) actions do not reach corporate mismanagement); Ernst \& Ernst v. Hochfelder, 425 U.S. 185 (1976) (scienter element of common law fraud required for implied section 10 actions); Blue Chip Stamps v. Manor Drug Stores, 421 U.S. 723 (1975) (potential plaintiff class limited to actual buyers and sellers of securities).

68520 F.2d 1373 ( 2 d Cir.), cert. denied, 423 U.S. 947 (1975). 
holders, ${ }^{69}$ and that implicit guarantees of trustworthiness accompanied a corporation's listing on the exchange. ${ }^{70}$ If that suggestion is correct, then the present statutory scheme fails to compensate for corporate misdeeds just as badly as it does when the injured investors sue the exchange. ${ }^{71}$

Suits against both the exchange and the listed corporation, therefore, are based upon the premise that Congress passed the 1934 Act in order to protect investors. Investors must argue that, given the absence of any express compensatory remedies, they must have been intended to have a right to sue for violations of listing agreements, which are entered into largely to afford them the intended protection.

\section{Obstacles to An Implied Private Right}

The difficulty with the argument for an implied private right of action is that courts have disfavored them during the past decade. This represents a marked change from cases decided between 1946 and 1960, notably involving sections $10(\mathrm{~b})$ and $14(\mathrm{a})$ of the 1934 Act, in which courts liberally granted plaintiffs private rights of action although the statute did not provide for them. ${ }^{72}$ The flood of federal securities litigation during the 1960 s was probably responsible for diminishing judicial enthusiasm for implied private rights in securities law, a trend culminating in the Supreme Court's decision in Cort $v . A s h .{ }^{73}$

Cort set forth a four-pronged test ${ }^{7 *}$ for analyzing asserted private rights, and four years later the Court refined that test in

69 "The duty of a listed company to its own securities holders to treat them fairly is founded in fundamental concepts of the law pertaining to corporate fduciaries." Id. $1382 \mathrm{n} .19$ (citations omitted).

70 [W] find inviting [the argument] that[,] to the American investing public[,] listing on the New York Stock Exchange carries with it implicit guarantees of trustworthiness. The public generally understands that a company must meet certain qualifications of financial stability, prestige, and fair disclosure, in order to be accepted for that listing, which is in turn so helpful to the sale of the company's securities. Similarly it is held out to the investing public that by dealing in securities listed on the New York Stock Exchange the investor will be dealt with fairly and Id. 1381. pursuant to law.

71 See text accompanying notes 53-63 supra.

72 J. I. Case v. Borak, 377 U.S. 426 (1964) and Mills v. Electric Auto-Lite Co., 396 U.S. 375 (1970), both decided under section 14(a) of the 1934 Act, 15 U.S.C. $\$ 78 \mathrm{n}(\mathrm{a})$ (1976), may be considered the high points of the implied right of action. See A. Frey, J. Choper, N. Leech \& C. Morrus, Cases and Materiats on CorPORATIONS 472-73 (1977).

73422 U.S. 66 (1975).

74 The four factors were (1) whether plaintiff is one of the class for whose especial benefit the statute was enacted; (2) whether there is any explicit or implicit 
Transamerica Mortgage Advisors, Inc. v. Lewis ${ }^{75}$ and Touche Ross of Co. v. Reddington. ${ }^{76}$ These cases made it more difficult for plaintiffs to meet the Cort test by emphasizing the need to show membership in the class for whose benefit the statute was enacted and to demonstrate legislative intent to create a private right. The latter requirement seems of critical importance, for the Court concluded in Transamerica that "what must ultimately be determined is whether Congress intended to create the private remedy asserted." 77

To overcome the argument by analogy to broker-dealer agreements, ${ }^{78}$ a court will likely point to the Supreme Court's recent focus on congressional intent in implication cases. The legislative history of sections 6 and 10 is silent about whether private parties were intended to have the right to enforce their provisions. Although the Supreme Court has said such slience "does not automatically undermine [the plaintiff's] position," 79 the Court has called it "hardly helpful to the [plaintiff]," 80 and a lower court would probably heed the Supreme Court's warning that "implying a private right of action on the basis of congressional silence is a hazardous enterprise, at best." 81

To counter the argument that the lack of a remedy to vindicate the statute's purpose and the scarcity of express sanctions against exchanges make a private right necessary, a court could point to sections $9(\mathrm{e}){ }^{82} 16(\mathrm{~b}),{ }^{83}$ and $18(\mathrm{a}){ }^{84}$ which explicitly grant private rights of action under certain circumstances. These sections demonstrate that "when Congress wished to provide a private damages remedy, it knew how to do so and did so expressly," ${ }^{85}$ and

legislative intent to create or deny a private right of action; (3) whether it is consistent with the purposes of the legislative scheme to imply a private right of action, and (4) whether the cause of action is one traditionally relegated to state law. See id. 78.

75444 U.S. 11 (1979).

76442 U.S. 560 (1979).

7744 U.S. at 15-16.

78 See notes $42-48$ supra and notes 53-57 supra \& accompanying text.

79 Transametica, 414 U.S. at 18.

$80 \mathrm{Id}$.

81 Touche Ross, 442 U.S. at 571.

8215 U.S.C. $\$ 78 \mathrm{i}(\mathrm{e})$ (1976).

8315 U.S.C. $\$ 78 \mathrm{p}$ (b) (1976).

84 15 U.S.C. $\$ 78 \mathrm{r}(\mathrm{a})(1976)$.

85 Touche Ross, 442 U.S. at 572. 
make it "highly improbable that "Congress absentmindedly forgot to mention an intended private action." "s8

In sum, the judiciary's recent reluctance to imply private causes of action is likely to result in rejection of the arguments for implication under section 6 in the listing agreement context. Moreover, the Court's apparent intention to minimize extension of section 10 private rights will probably prove fatal to plaintiffs proceeding under that section. ${ }^{87}$ Yet such actions seem the only way of insuring that investors will truly be protected, and that listing agreement enforcement will not lie completely within the exchange's discretion.

\section{B. Third-Party Beneficiary Theory}

If, contrary to this Comment's analysis, listing agreement provisions were to be construed as contracts between the listed corporation and the exchange, shareholders might seek to premise exchange or corporate liability on a third-party beneficiary theory. To fall within the class of "intended beneficiary" of a contract, a third party must show that it will gain pecuniary benefit from the promised performance and that the contract makes clear to the promisor that the benefit is a motivating cause of the contract for the promisee. ${ }^{88}$ Alternatively, an "intended beneficiary" may be found when a third party is a creditor of the promisee and the contract calls for performance in satisfaction of the obligation. ${ }^{89}$

Courts generally have struggled with the practical problems of forcing listing agreements into the mold of private contracts. The strain is revealed, for example, when the plaintiff is a prospective

${ }^{86}$ Transamerica, 444 U.S. at 20 (quoting Cannon v. University of Chicago, 441 U.S. 677, 742 (1979) (Powell, J., dissenting)).

In Baird v. Franklin, 141 F.2d 238 (2d Cir.), cert. denied, 323 U.S. 737 (1944), the court answered this argument by noting that:

Those three sections deal with special matters only indirectly germane to the regulation of securities exchanges; they provide for more unrestricted recovery than would be possible at common law; and they prescribe narrow statutes of limitation. Also, $\$ 28(\mathrm{a}), 15$ U.S.C.A. $\$ 78 \mathrm{bb}(\mathrm{a})$, directly states that "the rights and remedies provided by this chapter shall be in addition to any and all other rights and remedies that may exist at law or in equity."

Id. 245.

87 See Comment, Implication of Civil Liability Under the New York Stock Exchange Rules and Listing Agreement, 22 Vul. L. Rev. 130 (I976).

884 A. Corbin, Contracts $\$ 776$, at 18 (1951).

s9 Id. $\$ 774$. 
purchaser of corporate securities rather than a shareholder. Courts, following traditional contract analysis, have dismissed these actions on the formalistic ground of lack of privity. ${ }^{90}$

Two federal courts have addressed the question of third-party beneficiary status for current security-holders. ${ }^{.1}$ One permitted the action against an exchange, not an issuer, reasoning that the relation between the SEC and the exchange provided the requisite intent to benefit. ${ }^{92}$ This decision seems to merge contract theory with a private right of action, and may not survive the recent stringency in implying such private rights. ${ }^{93}$

No case has gone so far as to confer third-party beneficiary status on a shareholder suing a corporate issuer for breach of the listing agreement. Judge Oakes, writing for the court in Van Gemert $v$. Boeing Co., would have held that the plaintiff shareholders were creditors of the corporate issuer, and were therefore entitled to third-party beneficiary status according to the second test, ${ }^{94}$ but the majority did not reach the issue. ${ }^{95}$

In short, plaintiffs seeking to enforce listing agreements on a third-party beneficiary theory will, like those arguing for an implied statutory cause of action, need to make a strong showing that their potential status as plaintiffs was foreseeable and intended. But instead of being required to show congressional intent, these plaintiffs must show that the contracting parties intended them to benefit. With the difficulty of discerning intent from contractual language well established, theirs will likely be a heavy burden.

90 See generally 4 A. Corbin, Contracts $\$ 778$ (1951).

91 Compare O'Neill v. Maytag, 339 F.2d 764 (2d Cir. 1964) with Weinberger v. NYSE, 335 F. Supp. 139 (S.D.N.Y. 1971).

92 Weinberger, 335 F. Supp. at 145. But see Weinberger v. NYSE, 403 F. Supp. 1020 (S.D.N.Y. 1975) (holding that plaintiff had failed to establish right to recovery on third-party beneficiary theory).

The O'Neill court held that the district court had not abused its discretion in refusing to allow the plaintiff to amend his complaint to state a third-party beneficiary theory. The court held that such a claim did not arise under federal law. 339 F.2d at 770 .

93 See notes 72-87 supra \& accompanying text.

$94520 \mathrm{~F} .2 \mathrm{~d}$ at $1382 \mathrm{n} .19$.

95 Because third-party beneficiary claims are asserted under state contract law, it is necessary to analyze the conflict of laws rule regarding choice of law to govern the parties' rights. The Restatement sets forth general principles governing choice of law. Restatement (Second) of Conflict of Laws $\$ \$ 6,188$ (1971). For a brief choice of law analysis in such a case, see Weinberger, 335 F. Supp. at 142-43. It should be noted that the wide latitude granted to a court in making its choice of law determination is not conducive to establishing uniform rules governing shareholder rights under the listing agreement. 


\section{Listing Agreements' Legality Under Federal Securitres Laws}

In recent years, the Supreme Court has decided a number of cases defining the limits of permissible federal securities regulation. Each of the several limitations that the Court has established has a potential impact upon listing agreements' legality.

In Ernst \& Ernst $v$. Hochfelder, ${ }^{96}$ the Court closely scrutinized the relationship between a promulgated regulation and its authorizing legislation to insure that the regulation did not exceed the statutory grant of power. In Sante Fe Industries, Inc. v. Green ${ }^{97}$ and Burks $v$. Lasker, ${ }^{98}$ the Court addressed the problem of the permissible intrusion of federal securities law upon the state's traditional power to regulate corporations. Finally, in Gordon $v$. NYSE, Inc. ${ }^{99}$ the Court dealt with the tension between the anticompetitive nature of the securities laws and the pro-competitive aims of the antitrust laws.

\section{A. Delegated Authority and Listing Agreements}

The Supreme Court addressed the delegation problem ${ }^{100}$ in Ernst \& Ernst $v$. Hochfelder, ${ }^{101}$ interpreting the scope of rule 10b-5 and setting forth the proper standard for scrutinizing securities rules. The Court rejected the argument for an expansive reading of section 10 of the 1934 Act ${ }^{102}$ urged by the plaintiff and the SEC as amicus curiae, stating instead that:

Rule 10b-5 was adopted pursuant to authority granted ... under $\S 10(b)$. The rulemaking power granted to an administrative agency charged with the administration of a

86425 U.S. 185 (1976).

87430 U.S. 462 (1977).

83441 U.S. 471 (1979).

99422 U.S. 659 (1975).

100 See, e.g., Federal Power Comm'n v. Transcontinental Gas Pipe Line Corp., 365 U.S. 1 (1961).

101425 U.S. 185 (1976). In Hochfelder, the plaintiff suffered losses from a securities scheme and attempted to recover damages from the accounting firm which had audited the brokerage house. The suit was based on the theory that the accountants, by negligently performing audits, had aided and abetted a violation of section $10(b)$ and rule $10 \mathrm{~b}-5$. The plaintiff did not allege or prove the accountants' intent to defraud or knowledge of deception, and the Court held that, without proof of specific knowledge or intent, the action could not be maintained.

$102 \S 10,15$ U.S.C. $\oint 78 \mathrm{j}$ (b) (1976): "It shall be unlawful for any person ... [t]o use or employ, in connection with the purchase or sale of any security registered on a national securities exchange or any security not so registered, any manipulative or deceptive device ...." 
federal statute is not the power to make law .... Thus, despite the broad view of the Rule advanced by the Commission in this case, its scope cannot exceed the power granted the Commission by Congress under $\S 10(\mathrm{~b}) .{ }^{103}$

In short, the Court held that deference to the administrative body was not unlimited. Although agencies' interpretations of their enabling statutes were to be given great weight, the Court made clear that it would examine those interpretations, and regulations issued pursuant to them, to insure some relationship to congressional intent. The Court attached no express label to the proper degree of scrutiny, but its analysis in Hochfelder seemed to test the regulation's rationality in carrying out the enabling legislation's purposes. ${ }^{104}$

Although Hochfelder sets out the proper approach for judicial examination of securities regulations, it is important to realize that listing agreements present unique problems in applying the "rationality" test. For the Hochfelder Court was faced with a typical securities case, involving the validity of an SEC rule promulgated pursuant to an explicit congressional grant of authority. ${ }^{105} \mathrm{Be}$ cause stock exchanges' rulemaking power is limited only by the very broad purposes of the 1934 Act, ${ }^{106}$ the inquiry is more complicated.

103425 U.S. at $212-14$.

104 Hochfelder thus explicitly affirmed the Court's "rationality" analysis in prior securities rules cases. See, e.g., Merrill Lynch, Pierce, Fenner \& Smith, Inc. v. Ware, 414 U.S. 117, 130 (1973) ("germane to fair dealing or investor protection"). Cf. Federal Power Comm'n v. Transcontinental Gas Pipe Line Corp., 365 U.S. 1, 30 (1961) (Federal Power Commission did not act irrationally). For a general discussion of the types of scrutiny the Court has applied in different areas of the law, see G. Gunther, Cases and Materials on Constitutional Law 670-76 (10th ed. 1980).

The Court's probing inquiry in Hochfelder suggests that it may have applied a rational test "with bite." See id. 691-93. Nevertheless, this Comment treats the test as one of "mere" rationality, for the possible "bite" of examining "articulated rather than hypothesized purposes," id. 692 n.4, seems insignificant when the "purpose" is as broad as "protecting investors." See Merrill Lynch, 414 U.S. at 135 ("we conclude, as the Government suggests, that the relationship between [the exchange rule] and fair dealing and investor protection is "extremely attenuated and peripheral, if it exists at all." (quoting Brief for the United States as amicus curiae at 9)).

105425 U.S. at $212-14$.

106 The exchanges' statutory authority includes:

(1) ... the capacity to be able to carry out the purpose of this chapter... and ... to enforce compliance ... with ... the rules of the exchange.

(5) The rules of the exchange are designed to prevent fraudulent and manipulative acts and practices, to promote just and equitable principles of trade . . . and, in general, to protect investors and the public interest ....

1934 Act, $\$ 6(b), 15$ U.S.C. $\$ 78 f(b)(1976)$. 
Thus, instead of inquiring generally whether listing agreement provisions are legal rules that improperly exceed the stock exchanges' grant of authority, the question is specifically whether listing agreements properly advance the purposes that Congress intended exchanges to serve when it passed the 1934 Act. Thus, the listing agreement restrictions must be rationally related to the purposes for which Congress gave exchanges the power to regulate corporate activities.

Congress granted self-regulatory organizations the power to formulate rules which are, "designed to prevent fraudulent and manipulative acts and practices, to promote just and equitable principles of trade ... and, in general, to protect investors and the public interest . . . " ${ }^{107}$ Determining whether listing agreement restrictions are rationally related to these legislative purposes requires examination of the substance of the provisions.

Consideration of these provisions demonstrates that some are clearly related to the exchanges' command to protect investors and the public interest. For example, size, profitability, and shareholder distribution requirements directly reduce the possibility of stock price manipulations and "fly-by-night" corporations duping investors. ${ }^{108}$ But other provisions, such as the independent audit committee requirement and provisions relating to voting rights, pose more difficult problems.

In defense of these broader provisions, exchanges can argue that most preserve the rights of current equity holders by protecting them from mismanagement or dilution of their ownership and voting rights. ${ }^{109}$ This argument for a broad reading of the power to protect investors, however, may run afoul of the Court's narrow view in Hochfelder. Even if the broad view prevailed, the legality -of some provisions might still be a close question.110 But unless

1071934 Act, $\$ 6(b), 15$ U.S.C. $\$ 78 f(b)(5)$ (1976).

108 See notes $39-40$ supra \& accompanying text. Yet even these basic provisions can be challenged, because, for example, the AMEX is willing to list securities of corporations that the NYSE finds too small, speculative, or closely held. See note 39 supra. Do the investors on the one exchange require less protection than those on the other? In all likelihood, however, a rational relation test would permit each exchange to determine the meaning of "speculative" for itself.

$109 \mathrm{See}$ note 40 supra. In this regard the provisions may be analogized to the - preemptive rights granted to shareholders at common law and modified by state . corporation statutes. See, e.g., Dex. CodE ANN. tit. 8, §102(b)(3) (1975).

110 Under present case law, it would be very hard to justify voting rights provisions under the statutory language "prevention of fraudulent and manipulative . acts and practices." The "manipulative" language is also found in section 10(b) of "the 1934 Act, see note 102 supra, and the Supreme Court, labeling the phrase "virtually a term of art when used in connection with securities markets," has re: stricted its scope to cover only situations involving nondisclosure. Hochfelder, 425 
the degree of scrutiny is increased above the rationality standard, the open-ended mandate to "protect investors" should insure listing agreements' legal survival.111

\section{B. Federalism and Listing Agreements}

Two recent cases reveal the Supreme Court's growing concern about federal securities laws' effects on the traditionally state-regulated field of corporate conduct. Santa Fe Industries, Inc. $v$. Green, ${ }^{112}$ much discussed for its impact on "freeze-outs," is more significant to this Comment for its broader implications, which the Court elaborated upon in Burks v. Lasker. ${ }^{113}$

In Santa Fe, minority shareholders were "frozen out" of a public corporation that chose to "go private," and were forced to accept cash for their shares.114 These shareholders then brought suit, claiming that the transaction violated section $10(\mathrm{~b})$ of the 1934 Act. ${ }^{115}$ The Supreme Court held that the district court properly dismissed the complaint.

U.S. at 199. It would be anomalous, therefore, if the exchanges could make certain conduct culpable by promulgating a rule under the precise language that, if proper disclosures are made, bars a cause of action under present federal securities law.

The audit committee provision in NYSE listing agreements may be easier to justify as helpful in ferreting out corporate misconduct and protecting investors" interests than many of the older provisions governing voting rights. See SENATE Comm. on Banktng, Houstng \& Urban Affatrs, 94tr Cong., 2D Sess., Report of the SEC on Questionable and Iltegal Comporate Payments and Practices 67-69 (Comm. Print 1976).

111 "[T]he mere rationality test[,] ... when applied as articulated, leaves little doubt about the outcome; the challenged legislation is always upheld." Massachusetts Bd. of Retirement v. Murgia, 427 U.S. 307, 319 (1976) (Marshall, J., dissenting). Justice Marshall noted, however, that in applying the mere rationality test the Court had not adbdicated its responsibility to examine the legislation, but had "acted only after a reasonably probing look at the legislative goals and means, and at the significance of the personal rights and interests invaded." Id. 320 .

112430 U.S. 462 (1977).

113441 U.S. 471 (1979).

114 By forcing minority shareholders to accept cash in lieu of stock, the majority shareholder gains $100 \%$ control of the corporation. The potential unfairness to the minority shareholders, particularly in light of the ineffectiveness of statutory appraisal rights, has been much discussed. See, e.g., Borden, Going Private-Old Tort, New Tort or No Tort?, 49 N.Y.U. L. Rev. 987 (1974); Brudney \& Chirelstein, Fair Shares in Corporate Mergers and Takeovers, 88 HaRv. L. Rev. 297 (1974); Brudney \& Chirelstein, A Restatement of Corporate Freezeouts, 87 YALE L.J. 1354 (1978).

115 In Santa Fe, the defendant increased its $60 \%$ share of Kirby Lumber Corp. to $95 \%$ between 1968 and 1973 . To acquire complete control of Kirby, Santa Fe then created a wholly-owned subsidiary, to which it transferred cash and its Kirby stock in return for the new subsidiary's stock. Santa Fe then caused the new subsidiary to merge into Kirby with the 5\% "minority" receiving cash based on an independent banking firm's appraisal of the value of their shares. The merger took place under the Delaware short form merger law. DEL. CODE ANN. tit. 8, \$253 (1975). Full disclosure was made to the minority shareholder who, dissatisfied with 
First, the Court found that the plaintiff had failed to allege a material misrepresentation or failure to disclose, a necessary element of the section 10(b) cause of action. ${ }^{x 16}$ Second, the Court bolstered its conclusion in dicta by examining the interplay between state and federal law. ${ }^{117}$ Noting that private actions under section 10(b) were not created by explicit statutory language, the Court analyzed the case under the familiar Cort test for implying private rights of action under the federal securities laws. ${ }^{118}$ The dissenting shareholders' argument collapsed under the question "whether 'the cause of action [is] one traditionally relegated to state law," "119 for the Court was satisfied that the state law "appraisal remedy" 120 sufficiently occupied the field to preclude federal intervention. ${ }^{121}$

In short, the Court was hesitant to intrude upon the state's traditional sphere of corporate regulation, especially by expanding a judicially created cause of action.

Absent a clear indication of congressional intent, we are reluctant to federalize the substantial portion of the law of corporations that deals with transactions in securities, particularly where established state policies of corporate regulation would be overridden. ... " "Corporations are creatures of state law, and investors commit their funds to corporate directors on the understanding that, except where federal law expressly requires certain responsibilities

the cash offered, brought an action in federal court claiming that the unfairness of the offer to them violated section $10(\mathrm{~b})$ of the 1934 Act and rule 10b-5. Green v. :Santa Fe Indus., Inc., 391 F. Supp. 849 (S.D.N.Y. 1975) (dismissing complaint), rev'd, 533 F.2d I283 (2d Cir. 1976) (2-1 decision), rev'd, 430 U.S. 462 (1977).

116 Based on the lower court's finding that there was no misrepresentation or comission, the Court refused to extend section $10(\mathrm{~b})$ to cover substantive unfairness - of a merger where all aspects of the transaction were fully disclosed. 430 U.S. at 474. By contrast, the Delaware Supreme Court has held that state law requires judicial examination of such mergers to ensure "complete fairness." Singer v. -Magnavox Co., 380 A.2d 969 (Del. 1977).

117 "The language of the statute is, we think, "sufficiently clear in its context" to be dispositive here, but even if it were not, there are additional considerations that -weigh heavily against permitting a cause of action .... for the breach ... alleged in this complaint." Santa Fe, 430 U.S. at 477 (quoting Ernst \& Ernst v. Hochfelder, 425 U.S. 185, 201 (1976)). Justices Blackmun and Stevens did not join the portion . of the Court's opinion analyzing those considerations. 430 U.S. at 480-81.

118 See note 74 supra and text accompanying notes 73-77 supra.

119430 U.S. at 478 (quoting Piper v. Chris-Craft Indus., Inc., 430 U.S. 1, 40 (1977) (quoting Cort v. Ash, 422 U.S. 66, 78 (1975))).

120 See generally Manning, The Shareholder's Appraisal Remedy: An Essay for .Frank Coker, 72 YaLE L.J. 223 (1962).

121 "[A]s in Cort [422 U.S. at 84] and Piper [430 U.S. at 41], we conclude that - it is entirely appropriate in this instance to relegate respondent and others in his $\because$ situation to whatever remedy is created by state law." 430 U.S. at 478. 
of directors with respect to stockholders, state law will govern the internal affairs of the corporation." 122

The federalism arguments supporting the Court's decision in Santa $F e$ played a leading role in Burks v. Lasker. ${ }^{123}$ In Burks, shareholders of an investment company derivatively sued the company's directors for allowing an investment that resulted in a huge loss. The lower court, applying the "business judgment rule," granted summary judgment for the corporation. ${ }^{124}$ The court of appeals reversed, ${ }^{125}$ and the Supreme Court granted certiorari to decide "whether the disinterested directors of an investment company may terminate a stockholders' derivative suit brought . . . under the Investment Company and Investment Advisers Acts of 1940." 128

The Court, however, immediately shifted its analysis by stating that " $[t]$ o decide that question, we must determine the appropriate roles of federal and state law in such a controversy." 127 The critical

122 Id. 479 (quoting Cort, 422 U.S. at 84) (emphasis in Santa Fe).

123441 U.S. 471 (1979). This case was one of the many arising from the Penn Central Railroad bankruptcy. The defendant mutual fund had invested heavily in Penn Central commercial paper (unsecured short-term obligations) shortly before the collapse, and experienced a $\$ 60$ million loss when the corporation filed for reorganization. Shareholders of the company sued the directors derivatively under the Investment Company Act of $1940, \$ 36,15$ U.S.C. $\$ 80 \mathrm{a}-35$ (1976), for breach of fiduciary duty in failing to analyze this investment independently, and for blindly accepting the investment advisor's advice.

124 Lasker v. Burks, 426 F. Supp. 844 (S.D.N.Y. 1977), rev'd, 567 F.2d 1208 (2d Cir. 1978), rev'd, 441 U.S. 471 (1979). The district court reasoned that the decision by the corporation's litigation committee, composed entirely of outside directors, that the suit was not in the corporation's interest required dismissal.

The business judgment rule forbids courts from substituting their judgment for that of directors. At the time of the district court's decision, New York law was unsettled on the application of the rule when the judgment was made by a special litigation committee. Since then, the New York Court of Appeals has approved the rule's application to shareholder derivative suits. Auerbach v. Bennett, 47 N.Y.2d 619, 393 N.E.2d 994, 419 N.Y.S.2d 920 (1979). In a dramatic contrary decision, the Delaware Supreme Court ruled that, notwithstanding a decision not to sue by an independent litigation committee, lower courts were to use their own "business judgment" in determining whether to permit shareholder derivative suits. Zapata Corp. v. Maldonado, 430 A.2d 779 (Del. 1981). See generally Arsht, The Business Judgment Rule Revisited, 8 Horstra L. Rev. 93 (1980).

125 [T] he findings of Congress, the statutory scheme, and the relevant case law persuade us that the statutorily disinterested directors of a registered investment company were never meant to have the final word in determining whether it is in the best interest of a mutual fund to press claims against their co-directors, and the adviser ...., for breach of fiduciary duties.

567 F.2d at 1210 .

126441 U.S. at 473 . See 15 U.S.C. $\$ 80 \mathrm{a}-1$ to -50 (1976) (Investment Company Act); id. $\$ 80 \mathrm{~b}-1$ to -20 (Investment Advisers Act).

127441 U.S. at 473. 
issue before the Court, then, was not the business judgment rule's applicability to an investment company, but the question whether state law or federal securities policy governed shareholder derivative rights.

The Court assumed that the shareholders had an implied derivative cause of action under the Acts, ${ }^{128}$ and thereby had stated a federal claim. It therefore concluded that "the overriding federal law applicable here would, where the facts required, control the appropriateness of redress despite the provisions of state corporation law." " 129

In determining that the facts did not require federal law to govern derivative suits, the Court examined the general application of both state and federal law to corporate directors' powers, concluding that the former was "the font" and that the latter was "largely regulatory and prohibitory." 130 So, because federal securities legislation was enacted against the background of state corporation law, the Court held that state law properly governed unless it destroyed a federal right. In short, the "facts require" federal securities law to override state corporation law only when the state provision conflicts with an "identifiable federal policy or interest." " 131

The analysis in Burks, although involving specific federal statutes, seems likely to establish the framework for examining all occasions of state and federal overlap in the securities field. ${ }^{132}$ Thus, listing agreements must be tested for consistency with state corporation law and, if a conflict exists, it must be determined whether the agreements vindicate an identifiable federal policy. ${ }^{133}$

128 But see Transamerica Mortgage Advisors, Inc. v. Lewis, 444 U.S. 11 (1979) (private right under the Investment Advisers Act limited to voiding adviser's contract). Note that the applicability of the Santa Fe-Burks line of reasoning to a situation in which private rights of action are not implied is questionable.

129441 U.S. at 477 (quoting J.I. Case Co. v. Borak, 377 U.S. 426, 434 (1964)) (emphasis in Burks).

130 Id. 478. "[Federal securities law] often limits the exercise of directorial power, but only rarely creates it." Id.

131 Id. 479 (quoting Wallis v. Pan American Petroleum Corp., 384 U.S. 63, 68 (1966)). Because neither federal statute expressed congressional intent about directors' rights to cut off derivative suits, the Court remanded for determination of state law on the subject.

132 "[T] The threshold inquiry for a federal court . . . should have been to determine whether state law permitted [the corporation's] disinterested directors to terminate [the] suit. If so, the next inquiry should have been whether such a state rule was consistent with the policy of the [federal statutes]." Id. 480 .

133 Justice Blackmun's concurring opinion aptly summarized the Court's position: I read th[e] opinion to hold that on remand the Court of Appeals . . . should determine what the state law in this area requires, and then whether that state law is consistent with the policy of the Investment Company and Investment Advisers Acts. ... [I]t seems to me that a 
The substance of listing agreement provisions may play a determinative role in the question whether the agreements have impermissibly passed the limits of federal securities law. The federalism inquiry should focus upon those provisions that have been generally considered matters of state corporate law. Such provisions, including mandatory voting requirements and limitations on structure and composition of the board of directors, ${ }^{134}$ have the greatest chance of violating the pronouncements of Santa Fe and Burks.

The issue, then, is whether the listing agreement provisions are consistent with the Securities Act's identifiable policies. If so, then even in the event of a conflict with state law, Burks holds that federal law will prevail. Only if state law conflicts with listing agreement provisions and the provisions do not vindicate an identifiable federal policy or interest can the agreements be struck down. ${ }^{135}$

The 1934 Act's purpose is to do whatever is required to protect investors. But, "the principle . . . was that conflicting [state] law ... should be pre-empted by exchange self-regulation 'only to the extent necessary to protect the achievement of the aims of the Securities Exchange Act." " 136 The federalism claim, therefore, may

situation could very well exist where state law conflicts with federal policy. The effectuation of that federal policy should not then be foreclosed....

Id. 486-87.

134 See note 40 supra.

135 See Burks, 441 U.S. at $479-80$.

138 Merrill Lynch, Pierce, Fenner \& Smith, Inc. v. Ware, 414 U.S. 117, 127 (1973) (quoting Silver v. NYSE, 373 U.S. 34I, 361 (1963)) (emphasis added). The Court also stated that "any rule or practice not germane to fair dealing or investor protection would not appear to fall under the shadow of the federal umbrella; [the issue] is, instead, subject to applicable state law." Id. 130-31. Of course, the rule may still withstand scrutiny, provided that it is consistent with the state law. Id. 138.

Note that if the listing agreement provision fails to effectuate the Act's purposes, it will likely be invalid under the Hochfelder analysis. See notes 100-11 supra \& accompanying text. But, assuming that ordinary scrutiny applies, it seems clear that a "rational" argument can be made that these rules "protect investors." And, an aim of protecting investors probably would justify major incursions into the state law realm because it is premised on the nearly unlimited commerce power, which provided Congress the ability to enact the 1934 Act. For a general discussion of Congress's vast commerce clause power, see G. GuNTHER, supra note 104, at 153-212.

Stock exchanges have enough impact on interstate commerce to be extensively regulated. As the Court noted:

Stock exchanges perform an important function in the economic life of this country. They serve, first of all, as an indispensable mechanism through which corporate securities can be bought and sold. To corporate enterprise such a market mechanism is a fundamental element in facilitating the successful marshaling of large aggregations of funds that would otherwise be extremely difficult of access.

Silver v. NYSE, 373 U.S. 341,349 (1963). 
place more of a burden upon exchanges than the "mere rationality" standard enunciated in Hochfelder, for the exchanges must apparently show that listing agreement preemption of state law is necessary to vindicate the Act's policies. As the Court reiterated in Merrill-Lynch,

[t] he principle to be derived from our decisions is that federal regulation of a field of commerce should not be deemed pre-emptive of state regulatory power in the absence of persuasive reasons-either that the nature of the regulated subject matter permits no other conclusion, or that the Congress has unmistakably so ordained. ${ }^{137}$

In summary, sweeping listing agreement provisions that conflict with state law could fall under a federalism attack. But this result would occur only in the unlikely event that a court viewed the provisions as unnecessary to carry out the broad Securities Act policy of protecting investors.

\section{Antitrust Law and Listing Agreements}

Securities law, with its emphasis on self-regulation, is one of the early New Deal programs which countermanded the goal of competition in favor of a cooperative scheme of industrial selfgovernance. $^{138}$ Consequently, since the advent of securities regulation, the interaction between its provisions and those of the antitrust laws has been a matter of controversy, because:

[t]he difficult problem here arises from the need to reconcile pursuit of the anti-trust aim of eliminating restraints in competition with the effective operation of a public policy contemplating that securities exchanges will engage in self-regulation which may well have anticompetitive effects in general and in specific applications. ${ }^{139}$

Most judicial and legislative activity dealing with this conflict has focused on rules relating to broker-dealer members. Until recently, the most visible antagonism arose from the fixed minimum commission pricing scheme imposed by the stock exchange. ${ }^{140} \mathrm{Be}$ -

137 Florida Lime \& Avocado Growers, Inc. v. Paul, 373 U.S. 132, 142 (1963), quoted in Merrill Lynch, 414 U.S. at 139.

138 M. Paraish, Securtities Regulation and the New Deal (1970); E. Hawley, The New Deax and the Problem of Monopoly 35-52 (1966). See also Schechter Poultry Corp. v. United States, 295 U.S. 495 (1935) (industry codes of fair competition).

139 Silver v. NYSE, 373 U.S. 341,349 (1963).

140 These minimum commissions were a classic instance of "price fixing" and were the subject of intense debate in the late 1960s and early 1970s. The SEC 
cause the exchanges' rules are enforced by expulsion, violators are forced to deal with obedient members at an economic disadvantage.141 This economic punishment of one broker-dealer by a group of competitors, although permitted by the securities laws, clearly raises antitrust issues.

The Supreme Court has twice attempted to define the coordination of these incongruous laws, both times in the context of challenges to broker-dealer member rules. In Silver $v$. NYSE, ${ }^{142}$ the Court refused to exempt a rule from antitrust attack. In Gordon $v$. NYSE, ${ }^{143}$ the Court found a different rule to be beyond the reach of the antitrust laws. In Silver, the Court addressed a claim that an exchange rule requiring members to disconnect phone lines linking them to nonmembers was a conspiracy in restraint of trade. The nonmember plaintiff persuaded the district court that removal of the phones was a concerted refusal to deal and a per se Sherman Act violation. ${ }^{144}$ The court of appeals reversed, holding that the 1934 Act exempted the exchange from the Sherman Act "because it is exercising a power which it is required to exercise by the Securities Exchange Act." 145

The Supreme Court reversed. Acknowledging the philosophical conflict between the statutes, the Court sought to reconcile them by examining the procedural checks on exchange self-regulation. Because there was "nothing built into the regulatory scheme which performs the antitrust function of insuring that an exchange will not . . . apply its rules so as to do injury to competition which cannot be justified ....,"146 the Court concluded that the antitrust laws provided the only means for review of the rule. ${ }^{147}$

finally forced the abolition of minimum fees in 1975. Mann, The New York Stock Exchange: A Gartel at the End of Its Reign in Promoting Competrtion IN ReguLATED MARKETS 301 (A. Phillips ed. 1975).

141 Id. 302-03. See 2 NYSE GumE (CCH) I 1653 (1981).

142373 U.S. 341 (1963).

143422 U.S. 659 ( 1975 ).

144 Silver v. NYSE, 196 F. Supp. 209 (S.D.N.Y. 1961), rev'd, 302 F.2d 714 (2d Cir. 1962), rev'd, 373 U.S. 341 (1963). The case involved a NYSE rule allowing the exchange summarily to cut off communications between the exchange "floor" and a "wire member" whose business depended on these communications. See 373 U.S. at 344-45.

145302 F.2d at 721 . Although the SEC oversees the highly regulated securities industry, the Commission had no way of reviewing the rule's application to the plaintiff. See 373 U.S. at 357-58.

146373 U.S. at 358.

147 "Should review of exchange self-regulation be provided through a vehicle other than the antitrust laws, a different case as to antitrust exemption would be presented." Id. 360. The Court struck down the rule because the refusal to continue private wires "occurred under totally unjustifiable circumstances." Id. 361 . 
In Gordon $v$. NYSE, ${ }^{148}$ the Court considered the aforementioned rule fixing minimum commission rates. ${ }^{149}$ The Court followed Silver faithfully, holding that the SEC's "explicit statutory authorization ... [to] review ... all exchange rules and practices dealing with rates of commission . . ." 150 performed the "antitrust function" that the Silver Court had demanded.

The Court's analysis in these cases focused upon the "implied repeal" of antitrust laws. ${ }^{151}$ If an exchange rule violated the antitrust laws, it had to be both "'necessary to make the Securities Exchange Act work and even then [must repeal the Sherman Act] only to the minimum extent necessary." "152 Because of the similarity between broker-dealer rules and listing agreements, this analysis should also apply to the latter. ${ }^{153}$

There can be no application of the Gordon-Silver test, however, unless listing agreements violate the antitrust laws. Here the distinction between broker-dealer and listing agreement rules is important, for their different effects suggest different antitrust consequences.

Restrictive practices by broker-dealer associations can operate both to damage competitors and to reduce the quantity of securities firm services available to the public. ${ }^{154}$ For example, the denial of a membership to a broker-dealer injures both the broker-dealer, who cannot trade, and the public, who have a limited number of broker-dealers to patronize. This is a horizontal ${ }^{155}$ division of markets, and, absent immunity, might violate the antitrust laws. ${ }^{156}$

Justice Stewart, joined by Justice Harlan, dissented because he felt that antitrust laws should not be used "to enforce the Court's concept of fair procedures under a totally unrelated statute." Id. 370 .

148422 U.S. 659 ( 1975 ).

149 The SEC had abolished fixed rates effective seven weeks before Gordon was decided. See id. 662, 681-82.

150 Id. 685.

151 Implied repeal stands for the proposition that certain actions will be immune from the antitrust laws because they are justified by other laws. See id. 682-89. 162422 U.S. at 685 (quoting Silver v. NYSE, 373 U.S. 341, 357 (1963)).

153 One court followed this precise reasoning in considering the antitrust implications of listing agreements. Harding v. American Stock Exchange, Inc., 527 F.2d 1366 (5th Cir. 1976).

154 See, e.g., Baxter, NYSE Fixed Commission Rates: A Private Cartel Goes Public, 22 StAN. L. REv. 675 (1970).

155 The distinction between vertical and horizontal restraints of trade, although not always easy to define, is nonetheless central to enforcement of the antitrust laws. Horizontal restrictions operate at a single level in the distribution of goods and

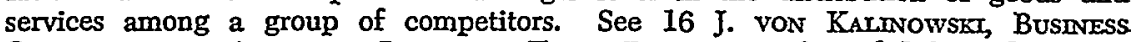
Organtzations: Antrtrust Laws and Trade Regulation $\$ 6.02$ [2] for a discussion of the variety of restraints of trade which have been tested under U.S. antitrust laws. 156 In general, such agreements are illegal per se. United States v. Topco Assocs., Inc., 405 U.S. 596 (1972); J. voN KAcINowsK, supra note 155, 
Listing agreement restrictions do not effect similar restraints. Corporations are not broker-dealers' competitors, so the restraint operates, if at all, vertically rather than horizontally. ${ }^{157}$ Furthermore, denial of listed status does not reduce the quantity of corporate securities available to the public because other markets for trading the securities are available. Under these circumstances, the vertical restraints imposed by the stock exchanges would at most be subjected to antitrust scrutiny under the "rule of reason." 158

Even if a court did find that a listing agreement provision violated the antitrust laws, a finding of antitrust immunity is almost compelled by the Silver-Gordon analysis. Examination of the listing agreement provisions by the $\mathrm{SEC},{ }^{159}$ and the significant role that listing plays in the Securities Act disclosure process, ${ }^{\mathbf{1 6 0}}$ justify application of the "implied repeal" theory to listing agreements. In a recent decision, Shumate \& Co. v. NYSE, ${ }^{161}$ a district court interpreted Gordon to mean that it was not required to conclude that a particular stock exchange rule was essential to carry out the purpose of the 1934 Act.162 Rather, the court made its inquiry whether "the implied repeal of the antitrust laws with respect to these... restrictions is necessary to effectuate the purposes of the Act. . . ."163 Using this theory, the court upheld NYSE Rule 390,164 a brazen form of market division forbidding members to trade NYSE listed securities on other exchanges or in the over-thecounter market. The rule has been severely criticized on anti-

$\$ 6.02[2][d]$. But see United States v. National Ass'n of Securities Dealers, Inc., 422 U.S. 694, 730-35 (1975) (holding alleged horizontal conspiracy to prevent growth of secondary market in mutual fund shares immune from antitrust attack because of SEC regulatory authority).

157 In contrast to horizontal agreements among competitors, vertical agreements occur between enterprises at different levels in the chain of distribution and production. J. voN KaLINOwSKI, supra note $155, \$ 6.02$ [1] provides examples of such restraints. The less severe effects of vertical restraints have led the courts to hold them permissible if reasonable and ancillary to a legitimate purpose. See, e.g., Continental T.V., Inc. v. GTE Sylvania Inc., 433 U.S. 36 (1977).

158 See Continental T.V., 433 U.S. at 36.

159 See note 45 supra.

160 See note 26 supra.

161486 F. Supp. 1333 (N.D. Tex. 1980).

162 The court quoted the Supreme Court's statement in Gordon that the " factual question as to whether fixed commission rates are actually necessary to the operation of the exchanges ... : [is different] from the legal question as to whether allowance of an antitrust suit would conflict with the operation of the regulatory scheme which specifically authorizes the SEC to oversee the fixing of commission rates." Id. 1339 (quoting Gordon, 422 U.S. at 688) (emphasis added).

163486 F. Supp. at 1343 (emphasis added).

164 Rule 390 forbids stock exchange members from trading in listed securities off the floor of the exchange. 2 NYSE GunE (CCH) II 2390 (1978). 
trust grounds and seems only minimally connected to effecting the purposes of the 1934 Act. ${ }^{165}$ It seems likely, therefore, that application of Shumate's reasoning would uphold the less restrictive listing agreement provisions. ${ }^{168}$

\section{Conclusion and Proposal}

\section{A. Conclusion}

Two commentators have recently suggested that the rules governing the conduct of large, publicly held corporations and their managers should be standardized, with officers, directors, and parent corporations owing their shareholders particular duties of loyalty. ${ }^{107}$ This Comment suggests that the correct source of these rules is not state corporation law, but the financial markets in which these firms' securities are traded. The advantages of this source of "regulation" are a much lower cost of information to investors and a properly adapted enforcement mechanism. ${ }^{108}$

The cost of information would be reduced by shrinking the number of regulatory regimes from fifty to two or three. Thus, stock exchanges would become an invaluable instrument for protecting investors from unsound investment choices by increasing the amount of information available to potential investors about the economic and legal rights that attach to an equity investment. As this lower cost of information encouraged more informed decisionmaking, investors would suffer fewer losses, and enforcement would rely less on the lengthy and costly judicial process invoked by investors' private actions. Instead, enforcement would proceed primarily through the delisting process.

Financial market "regulation," despite its advantages, presents potential legal problems. The most serious, stemming from the Hochfelder doctrine, is the possible finding that stock exchange regulation exceeds delegated authority or improperly intrudes

105 See Note, NYSE Rules and the Antitrust Laws-Rule 394-Necessary Restriction or Illegal Refusal to Deal, 45 ST. Jorn's L. REv. 812 (1971).

168 The listing agreement provisions most antagonistic to antitrust laws are the minimum size and distribution requirements, which effectively divide markets between, for example, the NYSE and the AMEX. See note 39 supra \& accompanying text. It is hard to imagine that these provisions could be vulnerable on antitust grounds, because they date back to the inception of the Sherman Act itself. Ch. 647, $\$ 1-6 \& 8,26$ Stat. 209-10 (1890). The economic impact of other provisions is far slighter, so it is difficult to see how they alone could fall.

167 Brudney \& Clark, A New Look at Corporate Opportunities, 94 HARv. L. Rev. 998, 1022-54 (1981).

168 See id. 1028-37 (costs and benefits of rules applied to full-time officers and executives). 
upon state corporate law. Such a finding is a real possibility where the exchange threatens to delist corporate securities to enforce the listing agreement, for delisting is a sanction approaching exercise of governmental authority by the exchange. A solution to this problem which maintains the informational and operational advantages of using the stock exchanges as a source of corporate "regulation" is outlined in the following proposal.

\section{B. Proposal}

It is proposed that the stock exchanges split their listed corporations into several classes. ${ }^{109}$ The first class would be corporations choosing to abide by stringent provisions of strengthened listing agreements. These requirements might include independent directors committees, such as audit, nomination, or compensation; ${ }^{170}$ procedures for handling stockholder litigation; ${ }^{171}$ submission to shareholders of offers to purchase the corporation's shares; ${ }^{172} \mathrm{mini}$ mum price requirements for final stage "freeze-out mergers" 173 and other provisions protecting shareholders' rights. The lower classes would consist of corporations choosing to abide by successively less restrictive listing requirements, mostly relating to size and profitability.

With a multi-class system, investors could be informed of the requirements each corporation has agreed to follow and could take these requirements into account in making their investment decisions. Corporations which breached their class requirements would be "relisted," but placement in a lower class would be a less severe

160 Two or three classes are probably preferable. This suggestion is admittedly somewhat arbitrary, for more classes would result in more flexibility. But this flexibility would be accompanied by a loss in the informational advantages of making fewer evaluations.

170 ABA Committee on Corporate Laws, The Overview Committees of the Board of Directors, 35 Bus. LAw 1335, 1351-60 (1980) (discusses the roles of various committees).

171 For example, putting some limitations on the ability of independent directors to have a derivative suit dismissed in the best interests of the company. See, e.g., Burks v. Lasker, 441 U.S. 471 (1979); Zapata Corp. v. Maldonado, 430 A.2d 779 (Del. 1981).

172 But see Lipton, Takeover Bids in the Target's Boardroom, 35 Bus. LAw. 101, 113-20 (1979) (rejecting automatic submission to shareholder vote of takeover bid on practical and policy grounds).

173 The model corporation code recognizes the need to protect minority shareholders in freeze-outs, and requires that the corporation include financial statements and notice of the shareholder's right to demand additional payment with remittances of fair value of the shares. MODEL Bus. CORP. ACT $\$ 81(f)(3)$. Cf. Coleman v. Taub, 638 F.2d 628, 631-36 (3d Cir. 1981) (protection for minority shareholders in freeze-outs guaranteed by Delaware law). 
punishment than delisting under the current regime. ${ }^{174}$ Thus, it is less likely that a court would find "coercion," a critical element in exercising delegated governmental power, and the Hochfelder problem would be avoided. Yet it would not be necessary to sacrifice the informational advantage of using the listing agreement to control corporate conduct.

The fixed income security market, where rating agencies such as Standard \& Poor's and Moody's classify bonds based on the obligor's credit characteristics and the terms of the obligation, ${ }^{175}$ provides a parallel to this proposed system. Obligors who fail to meet the requirements of a particular status have their rating lowered. Even though the rating agencies use up to ten categories, these ratings greatly reduce the information cost of assessing the value of the multitude of fixed income securities available in the investment marketplace

Of course, the rights of an equity securityholder are far more complex than a fixed income securityholder's rights. Equity securities, therefore, are less easily defined in contractual terms than fixed income securities. But, by increasing the extent to which equity securities can be cast in a contractual mold, the proposal alleviates some of the difficulty faced by courts and commentators in developing rules of corporate fiduciary behavior from the vague prescriptions of corporate law and precedent. To serve the public, such rules should flow from the needs of corporate issuers and investors, not from the judicial imagination.

174 Some of the serious consequences that may flow from delisting are detailed in note 48 supra.

175 See, e.g., Moody's Investors Service, Inc., Moody's Industrual Manuax (1980). For example, an increase in a corporation's debt to equity ratio can result in lower bond ratings because of the perceived increase in financial risk. See, e.g., Moody's Lowers Du Pont's Rating, N.Y. Times, Aug. 19, 1981, at D4, cols. 5-6. 